\title{
Environmental hazards of land use/land cover dynamics using data observation techniques and GIS: case study of Guyuan watershed, China
}

\author{
Hazem T. Abd El-Hamid ${ }^{1} \cdot$ Wei Caiyong $^{2} \cdot$ Zhang Yun $^{2} \cdot$ Ahmed M. El-Zeiny $^{3}$
}

Received: 30 September 2021 / Accepted: 28 January 2022 / Published online: 25 February 2022

(c) The Author(s) 2022

\begin{abstract}
Agricultural production system is extensively impacted by dynamics of land use. In the present paper, dynamics of land use and land cover (LULC) and environmental factors such as digital elevation model (DEM), slope, vegetation cover, soil type, and aspect were assessed to simulate the potential hazard in the watershed area at the southern part of Ningxia, Guyuan. This area was selected due to its wealthy fertile soils; thus, it provides food for multiple regions. Guyuan, Shilitan, and Yangcao cities were chosen as case studies. Multispectral Gaofen (GF) 2 satellite images and SRTM DEM were processed to produce environmental variables to assess the probable risks. In Shilitan watershed, very dense vegetation showed an increase from 14.6 to $22.1 \%$ and in Yangcao from 5.65 to $9.46 \%$ at 2005 and 2019, respectively, which protects the watershed area from flood and land degradation. However, spare vegetation recorded a decrease during the investigated period in two watershed areas. Hence, soil with little vegetative cover is more vulnerable to erosion, degradation runoff, and inconsequential water retention. DEM analyses showed that higher degree of segmentation leads to more degradation and damage of agricultural lands which adversely affects food security of the city. Results of the present study help policy makers, planners, and other accompanying development workers to apply the best suitable land use management options to protect Guyuan watershed.
\end{abstract}

Keywords Watershed · Environmental monitoring · Elevation · Hazards · Guyuan · Remote sensing · GIS

\section{Introduction}

The assessment of land use and land cover (LULC) in a watershed area is very important for soil conservation. Therefore, the Chinese government has recognized that it becomes very important to take an effective action to solve problems related to soil erosion in agricultural land located on the sharp slopes (Xu and Cao 2001). Changes of LULC in a watershed area are resulted from natural and/

Responsible Editor: Amjad Kallel

Hazem T. Abd El-Hamid

hazem_ecology@yahoo.com

1 National Institute of Oceanography and Fisheries (NIOF), Cairo, Egypt

2 Ningxia Institute of Remote Sensing Surveying and Mapping, Yinchuan 750021, China

3 Environmental Studies Department, National Authority for Remote Sensing and Space Sciences (NARSS), Cairo, Egypt or anthropogenic inducing factors. Studying the changes of LULC supports effective planning and modern development (El-Zeiny and Effat 2017; Abd El-Hamid et al. 2020).

On the other hand, natural increase in global average surface temperature leads to multiple difficulties due to global warming which appealed to the attention of different scientists, national organizations, and civil society groups (Mustafa et al. 2019). Additionally, the change in LULC is a main driving force of global change and essentially controls ecological processes, natural cycles, and exclusive biodiversity (Basommi et al. 2016). Further, the change in LULC is associated with development of the social economy; therefore, data on LULC is required for successful management of environment and living organisms. This information is widely used by planners, researches, and decision makers at local and regional scales for different applications. Majority of the applications involves evaluation of specific conditions in larger areas such as protected watershed zones and river basins (El-Zeiny and Effat 2017).

Shiferaw (2011) stated that urbanization, all over the world, induces the change of LULC. Generally, land use 
dynamics have multiple adverse impacts such as land degradation, habitat damage, loss of biodiversity, and endangered species (Meyer and Turner 1992). Watershed areas including several aspects of LULC may affect the watershed hydrological properties (Haque 2013). One of the main problems that face watershed area is vegetation distribution; therefore, physical geographers and ecologists have successfully related changes in vegetation types to environmental gradients at different diverse scales (Zhuang et al. 2012).

Watershed areas support the stockholders by the requirements of sustainable development for any region. At watershed areas, the excessive rain causes the accumulation of flowing water leading to more damage to the surrounded urban area (CGIA 1994; Abdel Hamid et al. 2020). To assess LULC changes and dynamics, the geospatial technologies (e.g., remote sensing, RS, and GIS) have significant role to provide regional data, rate of change, and LULC giving precise information (Dezso et al. 2005).

Guyuan is one of the ecologically important watersheds areas in Ningxia, China. In addition, it is considered an important city for food production since the fertility of soil helps farmers to plant many essential crops. RS and GIS are powerful techniques for assessing LULC changes over a specific period using spatiotemporal data. RS technology gives the advantage of regional coverage, short revisits, and low cost (Hong and Abd El-Hamid 2020).
Based on different landforms, China can be divided into 3 terrain ladders: East, Middle, and West with an obvious difference in economy and geography. Naturally, this difference will influence the local urban area; however, there was no previous study on the quantification of the differences in representative urban LULC (Quan et al. 2014). Therefore, the present study aims to integrate RS with GIS technology to assess the changes in Guyuan watershed, Ningxia, during the period from 2005 to 2019 .

\section{Materials and methods}

\section{Study area}

Guyuan district is situated in Ningxia which represents an environmentally remote fragile rocky frontier area of northcentral China (Fig. 1). This area has a potential evapotranspiration ranging from 1250 to $2000 \mathrm{~mm}$ and mean rainfall of $483 \mathrm{~mm}$ per year. Although the rain-fed agriculture is possible in the majority of the district, irrigated agriculture is probable in limited small areas. The farmers mostly engage in peasant farming due to the limited resources. Main growing crops are cereal crops as winter wheat, summer maize, and potato. The remaining land is mainly utilized for cultivating millet, buckwheat, oilseed plants, oats, beans, sweet potato, green vegetables, fruits, and fodder crops.

Fig. 1 Map of the study area

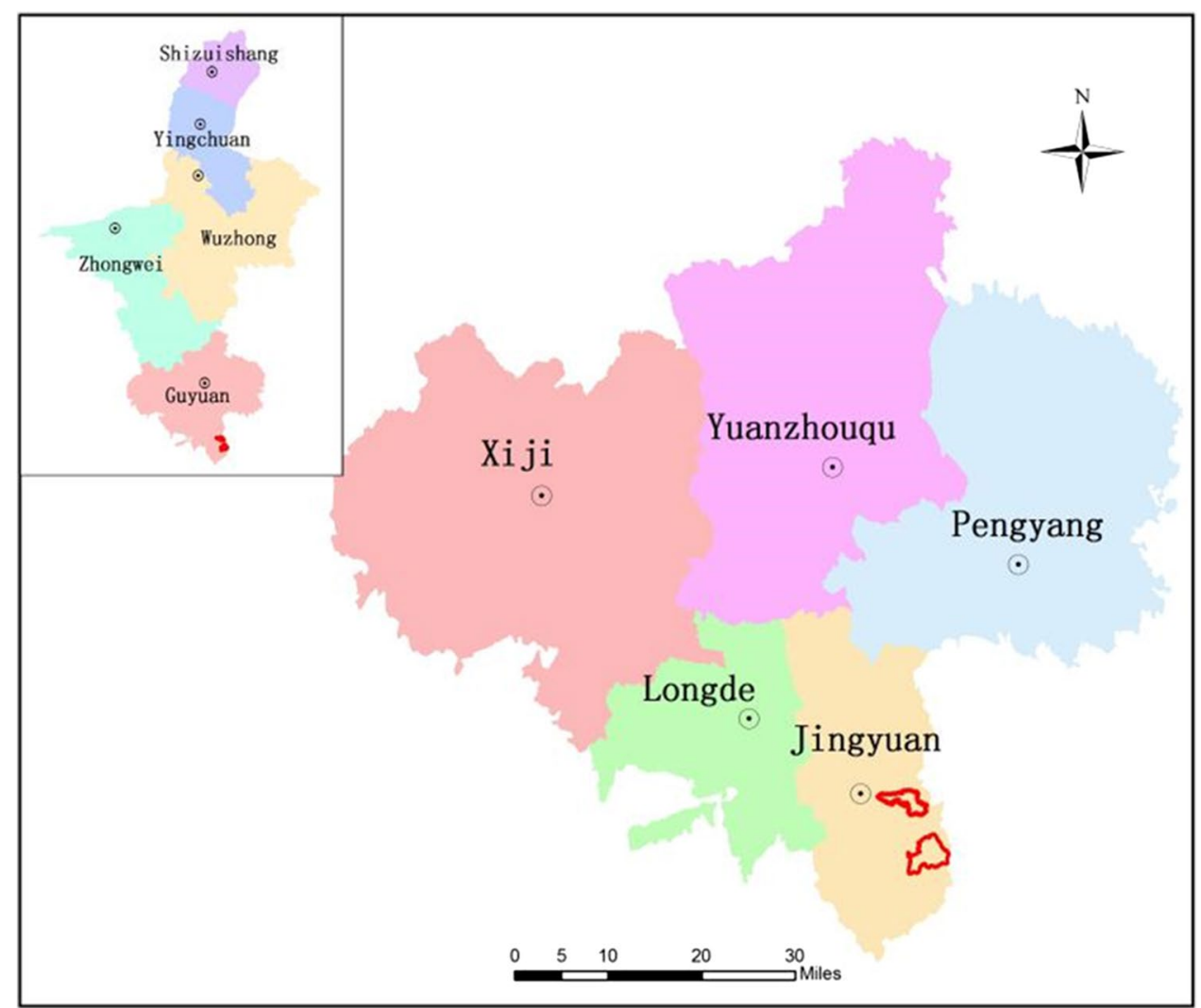



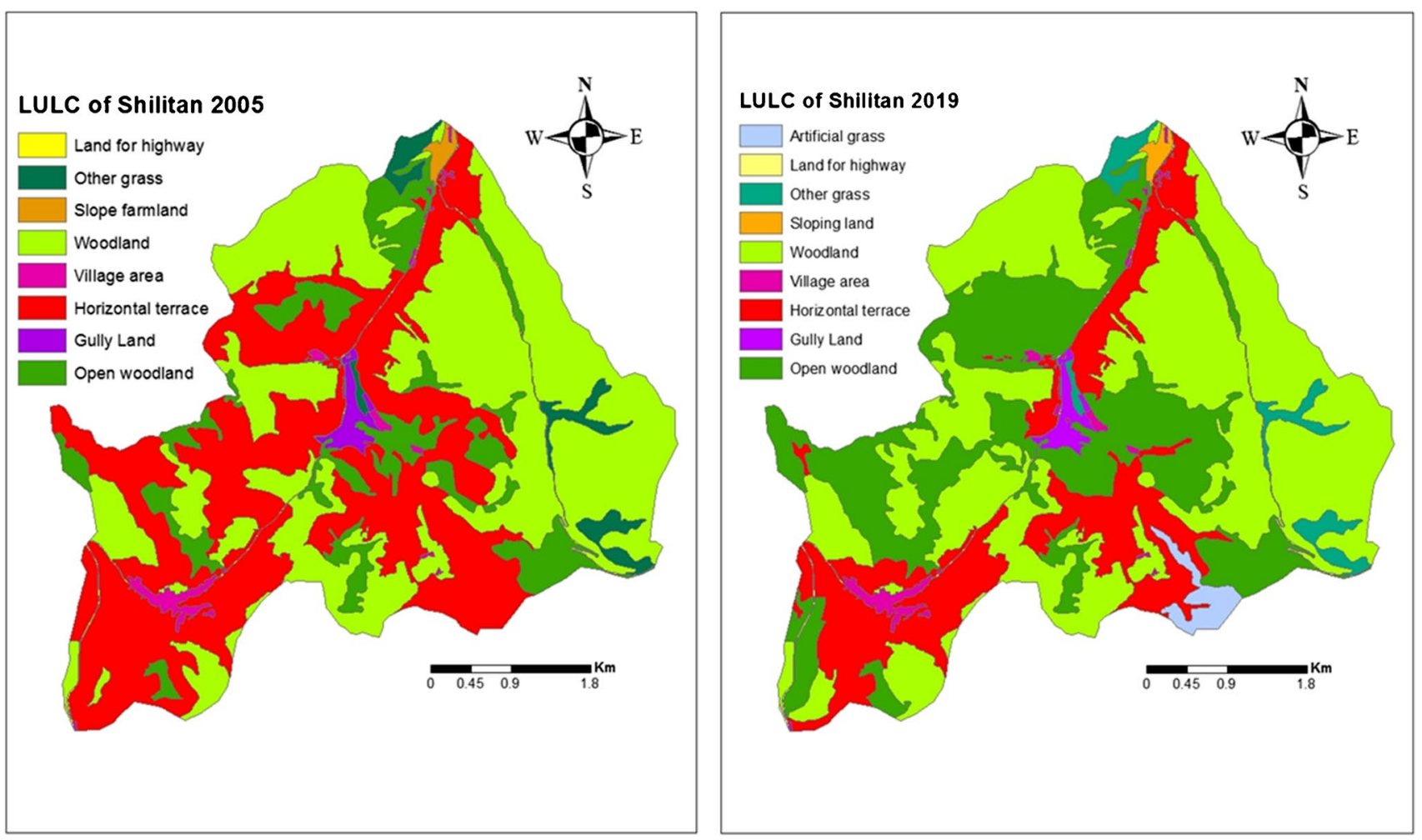

Fig. 2 Land use and land cover map of Shilitan city in 2005 and 2019

Table 1 Land use and land cover changes of Shilitan city in 2005 and 2019

\begin{tabular}{|c|c|c|c|c|c|c|}
\hline \multirow[t]{2}{*}{ Land use category } & \multicolumn{2}{|l|}{2005} & \multicolumn{2}{|l|}{2019} & \multicolumn{2}{|c|}{ Annual change } \\
\hline & Area (ha) & $\%$ & Area (ha) & $\%$ & Area (ha) & $\%$ \\
\hline Horizontal terrace & 1046.89 & 39.34 & 496.98 & 18.67 & -0.01476 & -1.4761 \\
\hline Woodland & 1155.88 & 43.43 & 1244.67 & 46.77 & 0.0023 & 0.24 \\
\hline Land for highway & 12.43 & 0.46 & 12.43 & 0.46 & 0 & 0 \\
\hline Village & 29.62 & 1.11 & 30.70 & 1.15 & 2.9E-05 & 0.0028 \\
\hline Sloping land & 10.77 & 0.40 & 10.77 & 0.40 & 0 & 0 \\
\hline Other grass & 66.56 & 2.50 & 66.56 & 2.50 & 0 & 0 \\
\hline Open woodland & 313.9 & 11.79 & 738.94 & 27.76 & 0.011 & 1.14 \\
\hline Gully land & 24.96 & 0.93 & 24.75 & 0.92 & $-5.6 \mathrm{E}-06$ & -0.00056 \\
\hline Artificial grass & - & - & 35.21 & 1.32 & - & - \\
\hline
\end{tabular}

The population density amounted to 142 persons per $\mathrm{km}^{2}$, and $89 \%$ of the population was employed as farmers (OGC 2007). During the month of May and September, the average of temperatures falls between $20{ }^{\circ} \mathrm{C}\left(68^{\circ} \mathrm{F}\right)$ and $25^{\circ} \mathrm{C}$ $\left(77^{\circ} \mathrm{F}\right)$. On average, the warmest month(s) are June and July. The coldest month is January with an average maximum temperature of $0{ }^{\circ} \mathrm{C}\left(30^{\circ} \mathrm{F}\right)$.

\section{Satellite data acquisition and watershed delineation}

In the present study, two Chinese Gaofen (GF) satellite images in 2005 and 2019 were used for further processing.
GF2 satellite data was selected as the main data source with the help of GF1 to fill the gap in the non-covered areas. The GF series satellites range from panchromatic, multi, and hyperspectral to optical radar with high spatial, temporal, and spectral resolution. Preprocessing procedure including radiometric, atmospheric, and geometric corrections were appropriately applied followed by layer stacking and cropping to resize the study area. Calibrations were required to eliminate errors occurred during acquisition procedure (ElZeiny and El-Kafrawy 2017; El Hamid et al. 2019). Then, additional landscape interpretation and topographic map (scale 1:100,000) following Standards of the National Land 

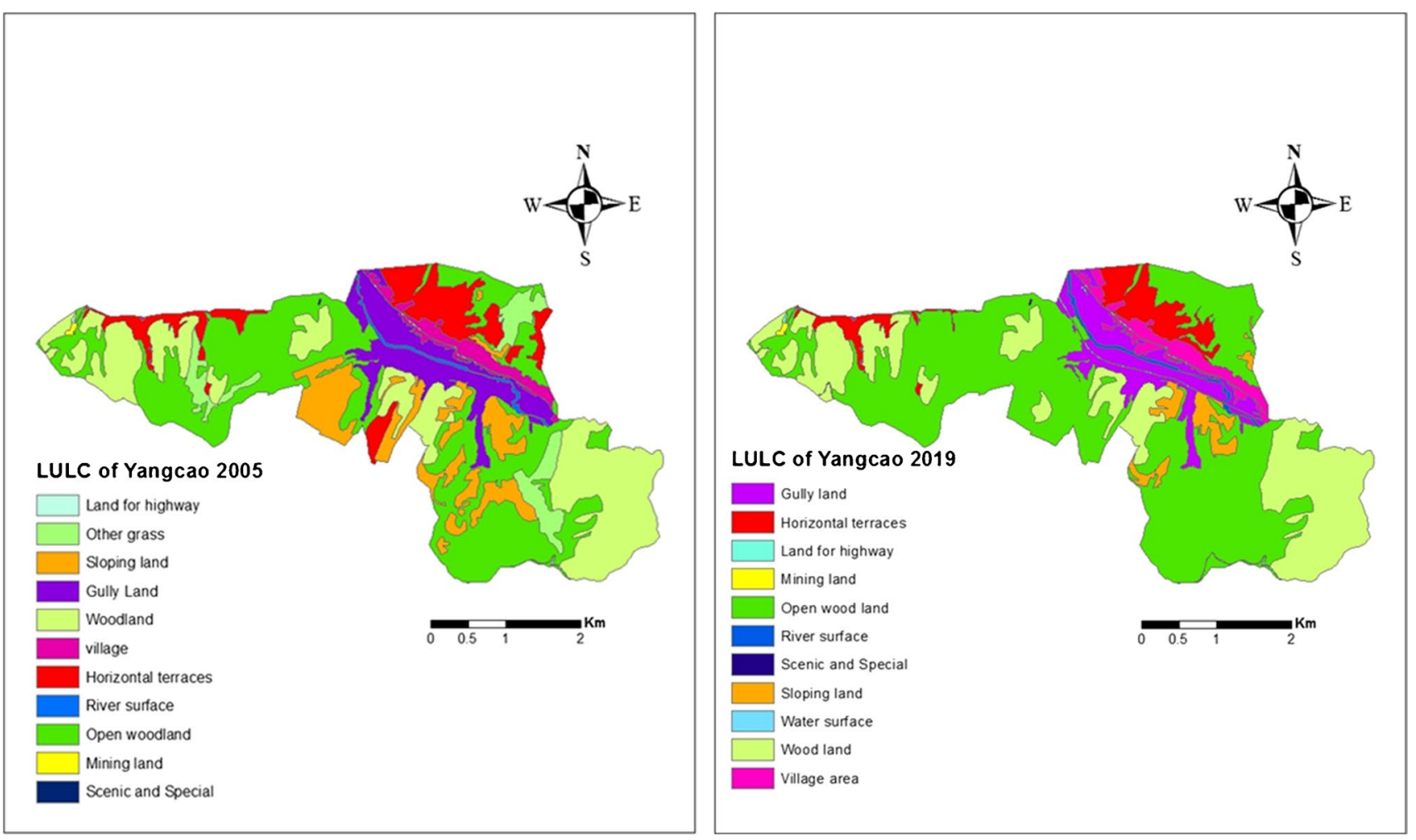

Fig. 3 Land use and land cover map of Yangcao city in 2005 and 2019

Table 2 Land use and land cover changes of Yangcao city in 2019

\begin{tabular}{|c|c|c|c|c|c|}
\hline \multirow[t]{2}{*}{ Land use category } & \multicolumn{2}{|l|}{2005} & \multicolumn{2}{|l|}{2019} & \multirow{2}{*}{$\begin{array}{l}\text { Annual change } \\
\text { Area (ha) }\end{array}$} \\
\hline & Area (ha) & $\%$ & Area (ha) & $\%$ & \\
\hline Scenic and special & 0.241033 & 0.014509 & 0.24103262 & 0.014509 & $-1.63 \mathrm{E}-11$ \\
\hline Gully land & 154.6582 & 9.30946 & 138.8265929 & 8.3565 & -0.000680 \\
\hline Woodland & 398.5629 & 23.99101 & 403.8151835 & 24.30717 & 0.000225825 \\
\hline Open woodland & 618.9307 & 37.25578 & 888.816563 & 53.50125 & 0.011603897 \\
\hline Land for highway & 4.68024 & 0.281721 & 8.787075808 & 0.528927 & 0.000176576 \\
\hline River surface & 12.00335 & 0.722527 & 12.63648275 & 0.760638 & 2.72219E-05 \\
\hline village & 48.51322 & 2.920195 & 58.73599556 & 3.535543 & 0.000439534 \\
\hline Mining land & 1.470021 & 0.088486 & 1.470021297 & 0.088486 & $1.27697 \mathrm{E}-11$ \\
\hline Other grass & 88.03074 & 5.298904 & - & - & - \\
\hline Sloping land & 181.2088 & 10.90765 & 47.16738357 & 2.839184 & -0.0057631 \\
\hline Horizontal terraces & 153.0015 & 9.209739 & 100.5572265 & 6.052921 & -0.002254871 \\
\hline Water surface & - & - & 0.247 & 0.0148 & - \\
\hline
\end{tabular}

Use Survey Classification were utilized. On the other hand, the watershed delineation is the creation of a boundary representing the contributing area for a control point. Several tools and software are used for automated delineation of watershed on the basis of DEM analyses (e.g., ArcGIS). Further, a GIS layer of stream network can be employed for watershed delineation (Braud 2009). Aspect and slope were derived from DEM processing.

\section{GF image processing and LULC transition}

For performing supervised classification of the calibrated GF satellite imageries, ERDAS Imagine V.14 software was used. Then, the resultant shapefile of the watershed area was employed for further processing of the GF images using ArcGIS 10.5. The supervised classification using the maximum likelihood classifier on ERDAS was used to produce LULC map for the two selected years. The investigated 
Fig. 4 Land use and land cover change map of Shilitan city in 2005

\section{Conversion of LULC from 2005 to 2019 in Shilitan}

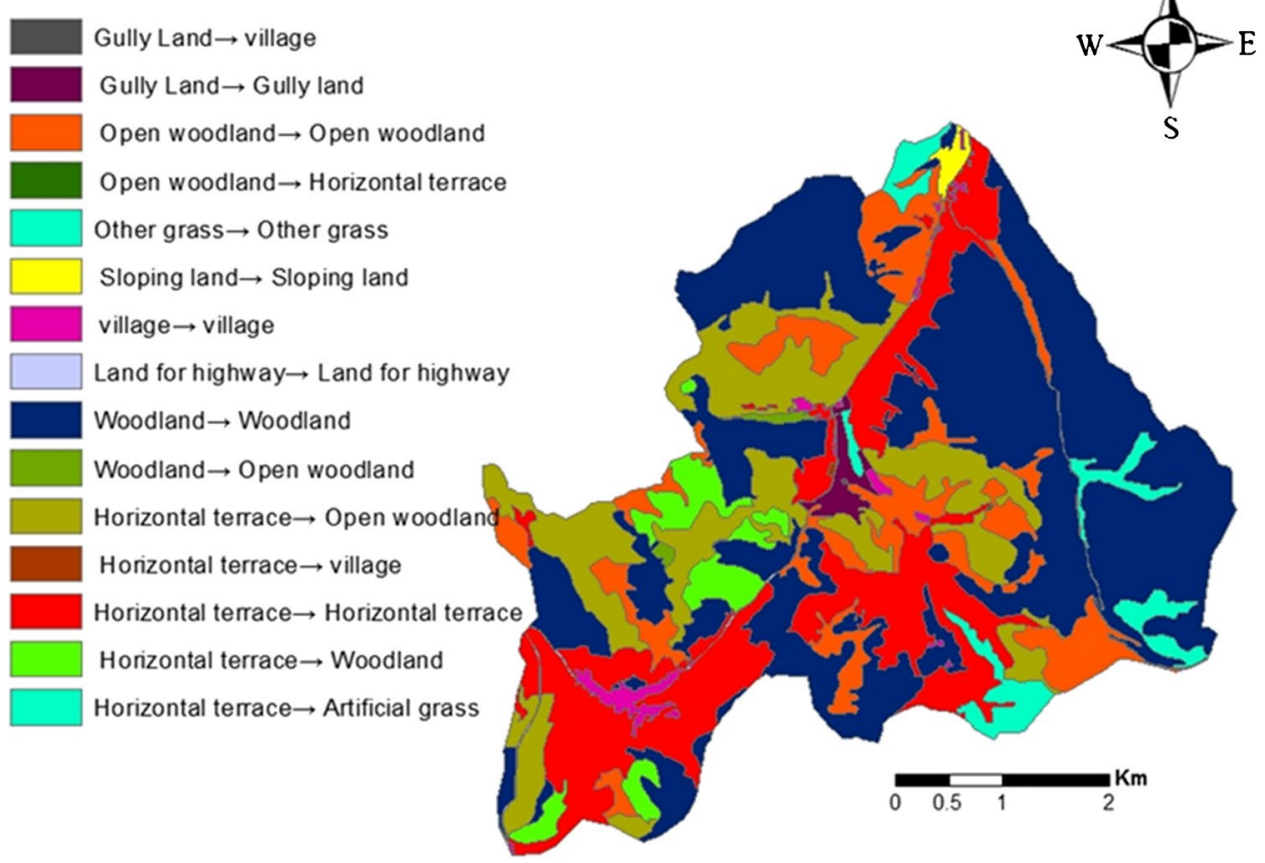

watershed area was classified into various classes, i.e., bare soil, vegetation, artificial grass, agriculture, water body, and settlements.

To assess dynamics of LULC, the land use transfer matrix was used. It is an analytical methodology to define the trend and transformation of land use type. Further, it can be used to assess the LULC changes and the gain/loss between various classes in 2005 and 2019. The transfer matrix was produced using the spatial analysis module in ArcGIS version 10.5 with integration of the function of Excel PivotTable according the below model:

$\left(\begin{array}{ccc}p_{11} & \cdots & p_{1 n} \\ \vdots & \ddots & \vdots \\ p_{n 1} & \cdots & p_{n n}\end{array}\right)$

$0 \leq p_{11<1}$

$\left.\sum_{i=1}^{n} p_{i j} x=1, i, j=1,2, \ldots \ldots, n\right)$

where $P_{i j}$ is the land area in transition from landscape $i$ to $j$.

\section{Vegetation cover}

Rouse (2020) used Landsat-1 MSS data to propose NDVI based on the characteristic considering that the reflectivity of all vegetation increases dramatically near $700 \mathrm{~nm}$. Thus, the NDVI can reflect surface vegetation coverage (El-Zeiny et al. 2022). Therefore, as the most common method, NDVI has been widely used in the study of algal extraction, which can eliminate the influences of terrain, shadow, and solar elevation angle.

$\mathrm{NDVI}=\frac{\mathrm{rNIR}-\mathrm{rRED}}{\mathrm{rNIR}+\mathrm{rRED}}$

where rRED and rNIR represent the reflectance of the red band and near-infrared band.

\section{Results and discussion}

\section{LULC of Shilitan and Yangcao watershed}

According to field observation and supervised classification, Shilitan watershed was divided into nine main land use/land cover classes as presented in Fig. 2. Classes of LULC were produced as follows, i.e., gully, horizontal, open woodland, other grass, woodland, highway, village, artificial grass, and sloping area, based on the approved standard classification. The LULC maps were developed for the years 2005 and 2019. Open woodland occupied the majority of the study area at the two selected years. In the present study, the watershed area was mostly covered with woodland, 43.43 and $46.77 \%$ in 2005 and 2019, respectively, as presented in Table 1 . On the other hand, sloping area resembles about $0.4 \%$ in 2005 and 2019. Moreover, artificial grass was observed in 2019 resembling $1.32 \%$ that can serve as a protection for the watershed from climatic change. Open 
Fig. 5 Land use and land cover change map of Yangcao city

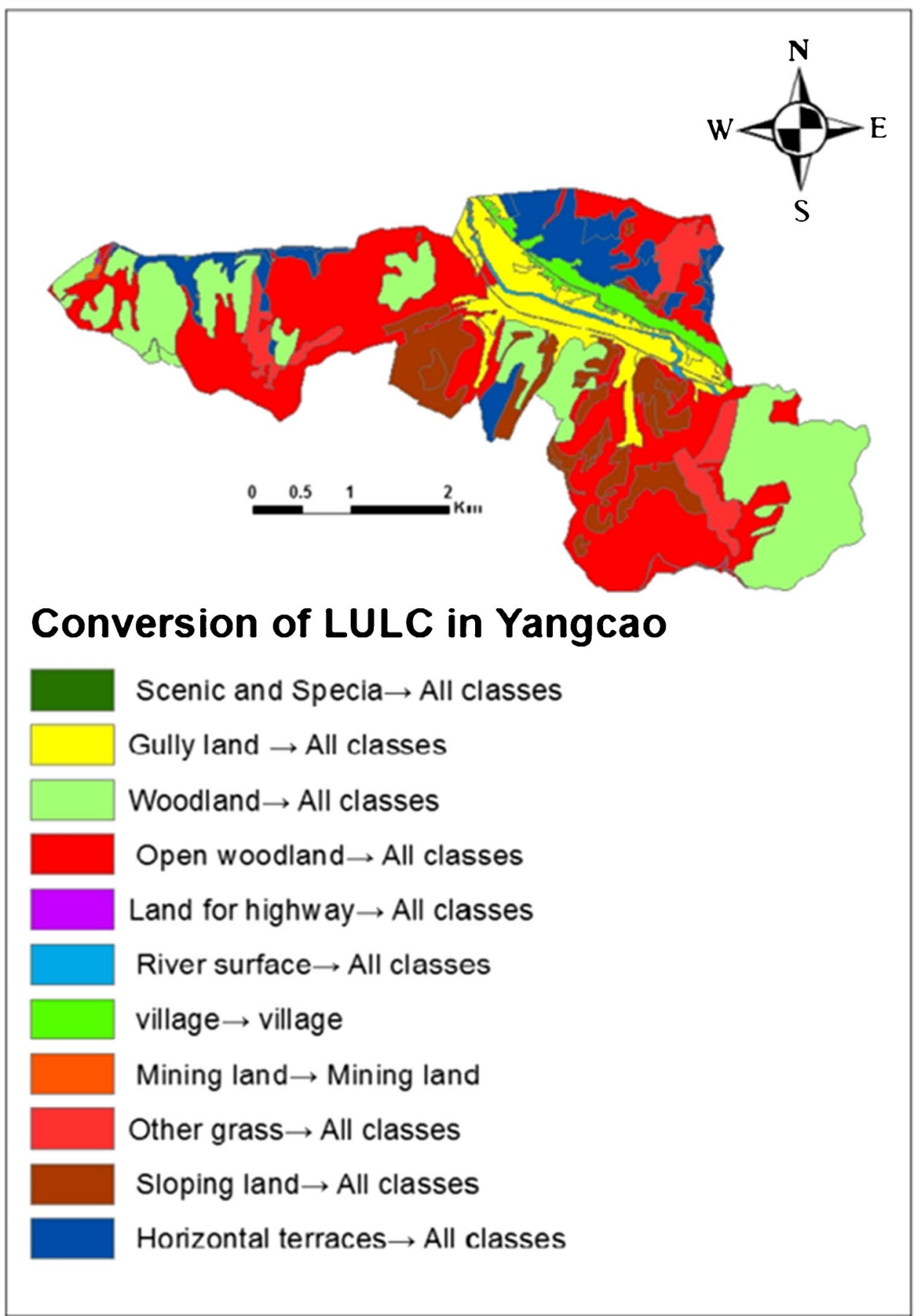

woodland reported the highest annual change from 2005 to 2019 with $1.14 \%$.

Twelve classes of LULC in Yangcao were produced as follows, i.e., scenic, gully, horizontal, open woodland, other grass, woodland, highway, village, mining, river surface, water surface, and sloping area, based on the approved standard classification. The LULC maps were obtained for the years 2005 and 2019 as presented in Fig. 3. As reported in Shilitan, open woodland also occupied the majority of Yangcao in two selected years. Watershed area of Yangcao was mostly covered with open woodland, 53.5 and $37.26 \%$ in 2005 and 2019, respectively, as presented in Table 2 . The decline of open woodland in Yangcao reflects the negative impact of heavy rainfall in the study area. It was shown that water surface was hidden in 2019 but other grass was added in 2019 as a result of increasing soil fertility. It was also shown that sloping area represented 2.83 and $10.9 \%$ in 2005 and 2019 , 
Table 3 Cross tabulation of Shilitan city from 2005 to 2019

\begin{tabular}{|c|c|c|c|c|c|c|c|c|c|}
\hline & Gully & Horizontal & Highway & Open woodland & Other grass & Sloping & Village & Woodland & Total in 2019 \\
\hline Artificial grass & - & $35.21 * *$ & - & - & - & - & - & - & 35.21 \\
\hline Gully land & 24.76 & - & - & - & - & - & - & - & 24.76 \\
\hline Horizontal terrace & - & 496.81 & - & $0.18 * *$ & - & - & - & - & 496.99 \\
\hline Land for highway & - & - & 12.44 & - & - & - & - & - & 12.44 \\
\hline Open woodland & - & $417.06^{*}$ & - & 313.73 & - & - & - & $8.15^{* *}$ & 738.94 \\
\hline Other grass & - & - & - & - & 66.57 & - & - & - & 66.57 \\
\hline Sloping land & - & - & - & - & - & 10.77 & - & - & 10.77 \\
\hline Village & $0.20 *$ & $0.87 *$ & - & - & - & - & 29.63 & - & 30.71 \\
\hline Woodland & - & $96.94 *$ & - & - & - & - & - & 1147.73 & 1244.67 \\
\hline Total in 2005 & 24.96 & 1046.89 & 12.44 & 313.91 & 66.57 & 10.77 & 29.63 & 1155.88 & 2661.06 \\
\hline
\end{tabular}

*Loss and **gain

Table 4 Cross tabulation land cover map of Yangcao city from 2005 to 2019

\begin{tabular}{|c|c|c|c|c|c|c|c|c|c|c|c|c|}
\hline & Gully & Horizontal & Highway & Mining & Open wood & River & Scenic & Water & Sloping & Village & Wood & Total in 2019 \\
\hline Gully land & 134.32 & - & - & - & $0.01 * *$ & - & $0.25 * *$ & - & $4.25^{* *}$ & - & - & 138.83 \\
\hline Horizontal & - & 96.33 & - & - & - & - & - & - & $4.23 * *$ & - & - & 100.56 \\
\hline Highway & 2.84 & - & 4.54 & - & $0.86^{* *}$ & - & $0.09 * *$ & - & - & - & $0.45^{* *}$ & 8.79 \\
\hline Mining & - & - & - & 1.47 & - & - & - & - & - & - & - & 1.47 \\
\hline Open woodland & $7.98 *$ & $49.79 *$ & $0.14 *$ & - & 613.89 & 88.03 & - & - & 126.36 & - & $2.62 * *$ & 888.82 \\
\hline River & 0.98 & - & - & - & - & - & 11.66 & - & - & - & - & 12.64 \\
\hline Scenic & - & - & - & - & - & - & - & 0.24 & - & - & - & 0.24 \\
\hline Sloping & 1.75 & $3.44 *$ & - & - & $3.10^{*}$ & - & - & - & 38.88 & - & - & 47.17 \\
\hline Village & $6.53 *$ & $2.61 *$ & - & - & $1.08^{*}$ & - & - & - & - & 48.51 & - & 58.74 \\
\hline Water & $0.25 *$ & - & - & - & - & - & - & - & - & - & - & 0.25 \\
\hline Wood & - & 0.83 & - & - & - & - & - & - & $7.50 *$ & - & 395.4 & 403.82 \\
\hline Total in 2005 & 154.66 & 153.00 & 4.68 & 1.47 & 618.93 & 88.03 & 12.00 & 0.24 & 181.21 & 48.51 & 398.5 & 1661.30 \\
\hline
\end{tabular}

*Loss and **gain

respectively. The increase in sloping area also reflects the hazard of any flood in the study area. It is indicated that woodland plays a vital role in sustainable development of vegetation and also in hydrology system of the city. High amount of woodland can prevent infiltration of more rainfall decreasing the hazard of soil erosion. Decrease in the sloping area can serve the environment of the watershed. Haque (2013) stated that woodland can minimize the hazard of flood. Present analyses showed that Shilitan watershed is safer than Yangcao watershed. According to Abd El- Hamid (2020), LULC changes are controlled by contribution of environmental, geographical and socioeconomic factors.

The global vegetation cover is continuously damaged to cope with the increasing requirements of population (Chowdhury et al. 2020). Analyses of LULC showed that Guyuan is obviously characterized by the change in agricultural lands and urban and industrial areas. The urban and industrial development leads to increases in industrial and mining areas on the expense of the grass lands (Quan et al. 2014). There are multiple factors inducing the change in grass lands, forest, and arable lands. These factors include, for instance, duration on sunshine, nutrient concentrations in the soil, elevation, and population income (Zhen et al. 2014).

\section{LULC transition of Shilitan and Yangcao watershed}

Transition of LULC in Shilitan and Yangcao watershed from 2005 to 2019 is shown in Figs. 4 and 5. These transitions reflect the developmental activities in the study area. In Shilitan, some classes remained with no change from 2005 to 2019 as gully area, highway, other grass, and sloping land as shown in Table 3. Artificial grass is the adding class from 2005 to 2019 resembling 35.21 ha on the expense of horizontal area. It was observed that horizontal area lost about 514.87 ha and gully area lost only 0.20 ha. Open woodland gained larger area from 2005 to 2019 on the expense of horizontal area. 

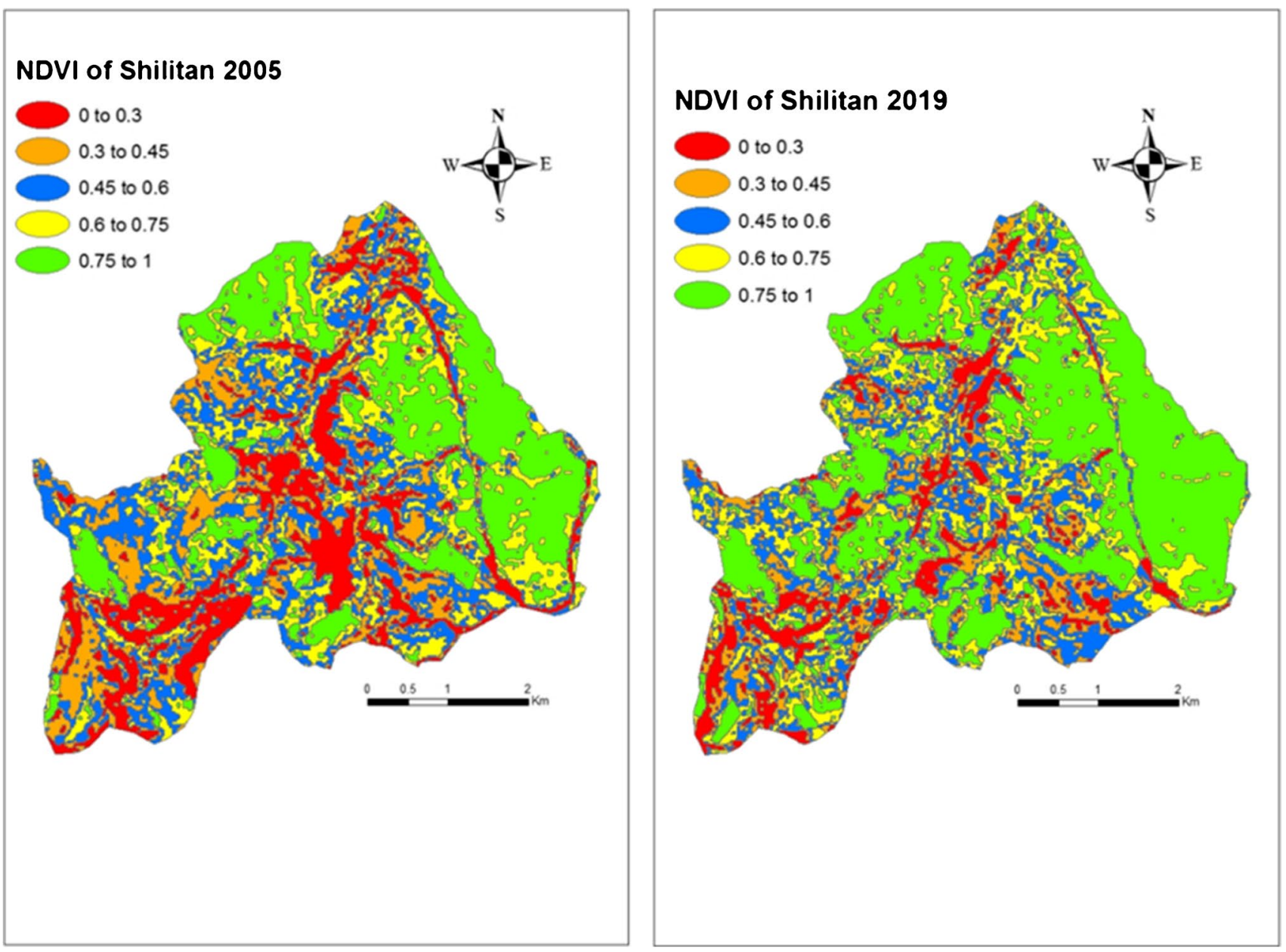

Fig. 6 Spatial distribution maps of NDVI in Shilitan watershed area at 2005 and 2019

The loss in horizontal area and increase in open woodland increase the protection of watershed area against climatic change especially high rainfall (Meshesha et al. 2016). In Yangcao, some classes reported no change from 2005 to 2019 as mining and scenic as shown in Table 4. Obviously, open woodland gained large area from sloping land which probably causes adverse effect on agriculture in the future causing flood in the watershed area.

\section{Vegetation cover of Shilitan and Yangcao watershed}

Vegetation cover of watershed area was mapped using Normalized Differential Vegetation Index (NDVI). NDVI of the two areas, Shilitan and Yangcao, was classified into five classes. It was found that healthy vegetation recorded high NDVI values and water bodies reported negative NDVI values because water absorbs electromagnetic energy. Further, bare lands' soil recorded NDVI close to zero due to the high reflectance in VIS and NIR bands (Lilles and Kiefer 1994). The NDVI map in 2005 and 2019 is shown in Figs. 6 and 7.
Further, the classification of NDVI is given in Tables 5 and 6. The NDVI indicated the following ranges: from 0 to 0.45 for sparse, 0.45 to 0.6 for medium, 0.6 to 0.75 for dense, and from 0.75 to 1 very dense cover. In Shilitan watershed, very dense vegetation increased from 14.6 to $22.1 \%$ at 2005 and 2019 , respectively. Increasing the area of dense vegetation increases the conservation of the area against heavy rainfall. In Yangcao, very dense vegetation increased from 5.65 at 2005 to $9.46 \%$ at 2019 . On the other hand, spare vegetation decreased from 2005 to 2019 in two watershed areas. It is well known that the land covered by little vegetation cover becomes more susceptible to degradation runoff and erosion. Elevated vulnerability to runoff occurred in erosion sheet and extended to rills. The topsoil was also removed from the upper land to the down land causing severe problems such as water pollution, waterborne diseases, and deposition of sediment on the fertile farms. These problems are found in many regions on the earth (Meshesha et al. 2016 and ElZeiny et al. 2022). 

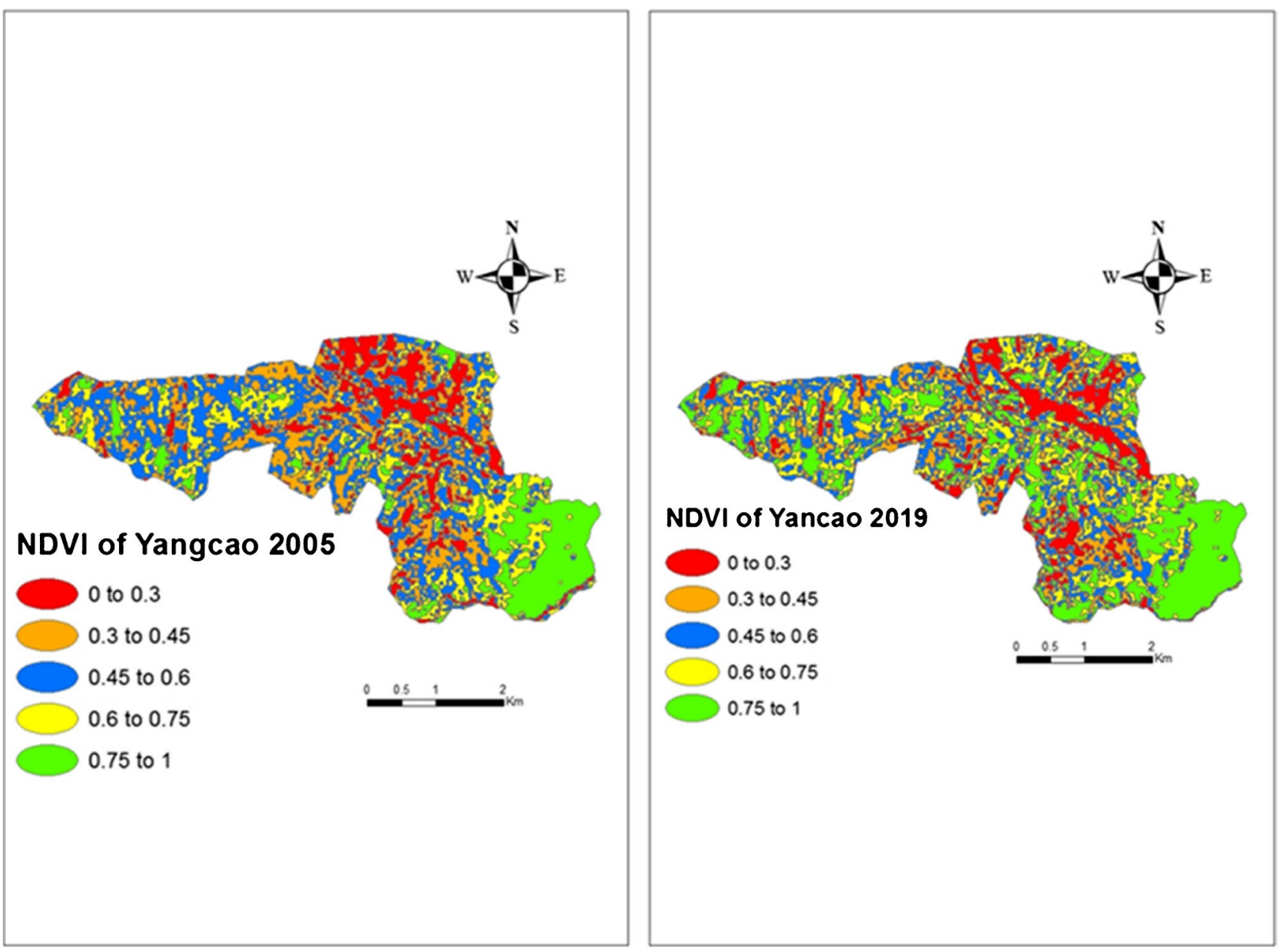

Fig. 7 Spatial distribution maps of NDVI in Yangcao watershed area at 2005 and 2019

Table 5 NDVI classification of Shilitan watershed

\begin{tabular}{llllll}
\hline NDVI classification & \multicolumn{2}{l}{2005} & & \multicolumn{2}{l}{2019} \\
\cline { 2 - 3 } \cline { 6 - 6 } \cline { 6 - 6 } & Area (ha) & $\%$ & & Area (ha) & $\%$ \\
\hline Spare & 885.67 & 18.98 & & 579.75 & 12.38 \\
Moderate & 569.68 & 12.20 & & 485.37 & 10.37 \\
Dense & 520.47 & 11.154 & & 560.97 & 11.98 \\
Very dense & 685.22 & 14.68 & & 1034.95 & 22.11 \\
\hline
\end{tabular}

Table 6 NDVI classification of Yangcao watershed

\begin{tabular}{llllll}
\hline NDVI classification & \multicolumn{2}{l}{2005} & & \multicolumn{2}{l}{2019} \\
\cline { 2 - 3 } \cline { 6 - 7 } \cline { 6 - 7 } & Area (ha) & $\%$ & & Area (ha) & $\%$ \\
\hline Spare & 593.75 & 12.72 & & 467.67 & 9.99 \\
Moderate & 502.97 & 10.77 & & 365.49 & 7.80 \\
Dense & 300.76 & 6.44572 & & 385.25 & 8.23 \\
Very dense & 263.81 & 5.65 & & 442.87 & 9.46 \\
\hline
\end{tabular}

\section{Factors affecting vegetation cover in watershed area}

There are many factors that affect the environment of watershed zones. In the present study, some factors were selected as DEM, slope, aspect, and soil type (Figs. 8 and 9). DEM plays an important role in the interpretation of watershed. DEM was utilized to produce maps of altitude and to assess their probable effect on the vegetation cover patterns. Moreover, the higher degree of segmentation leads to increase the intensity of degradation and loss of cultivable soil. In addition, Tegene (2002) discussed that the fast extension of agriculture into sharper slope is more vulnerable to degradation by erosion in Ethiopia. Likewise, Amede et al. (2001) demonstrated damage of vegetation cover as a result of expanding the practices of farming in sharper slopes specifically in the elevated lands of Ethiopia causing depletion of fertile soil. On the other hand, the lower altitude regions are further appropriate for 


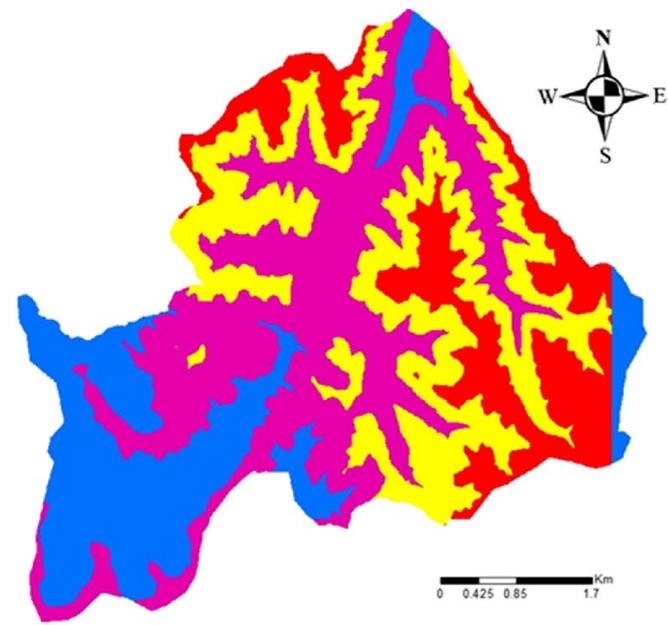

DEM of Shilitan area

\section{<VALUE>}

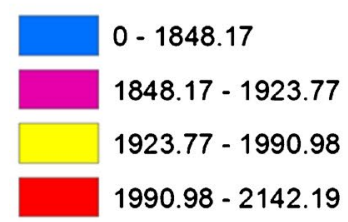

\section{Slope of Shilitan}

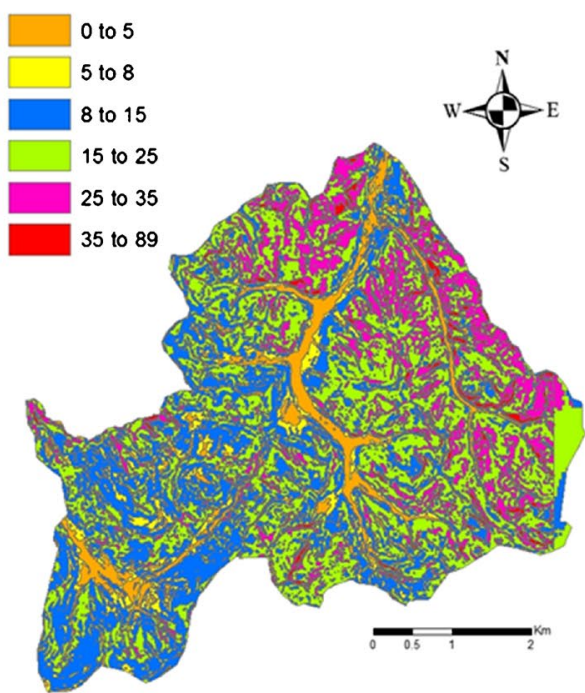

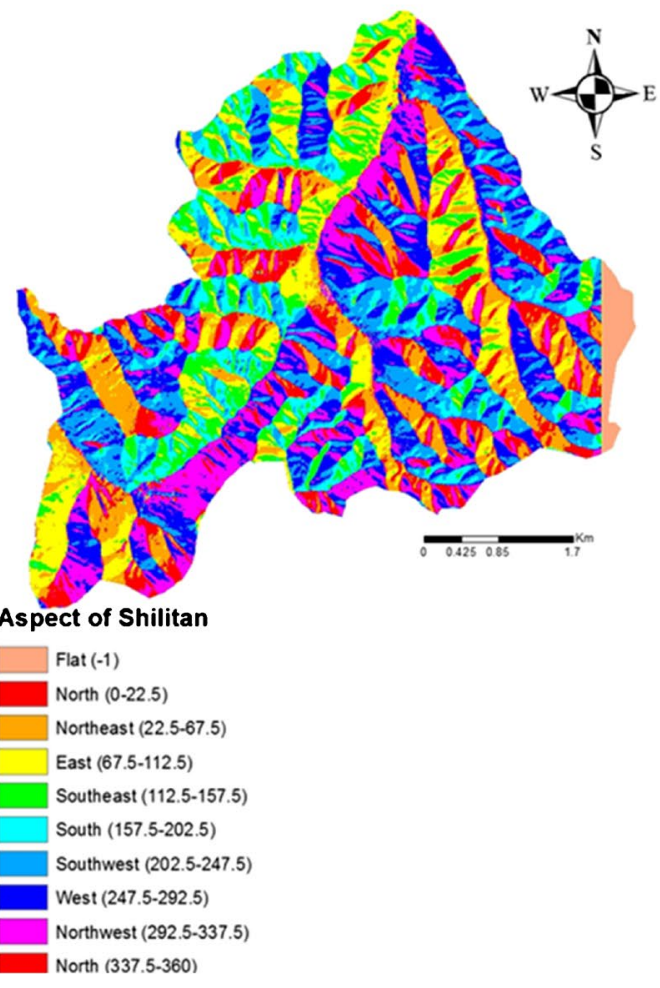

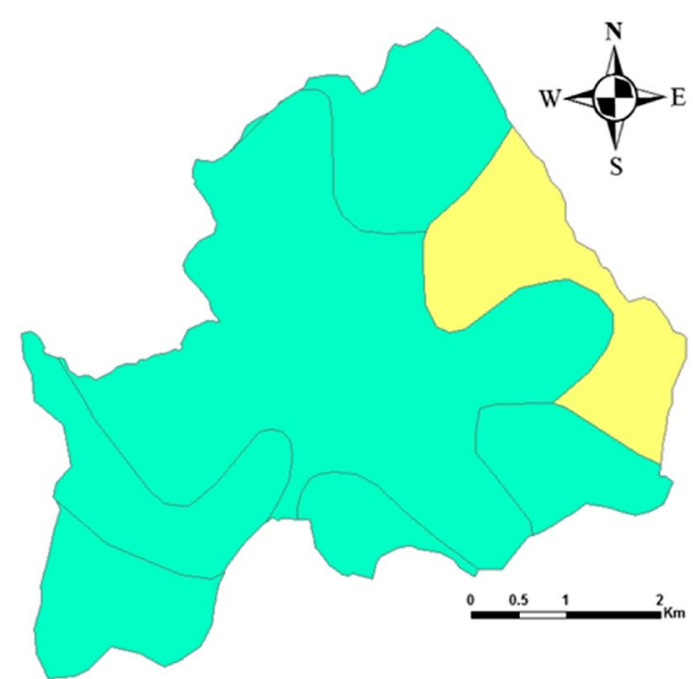

\section{Soil type of Shilitan area}

Dark grey soil

Calcareous grey soil

Fig. 8 Spatial distribution of DEM, slope, aspect, and soil in Shilitan city 


\section{DEM of Yangcao area}

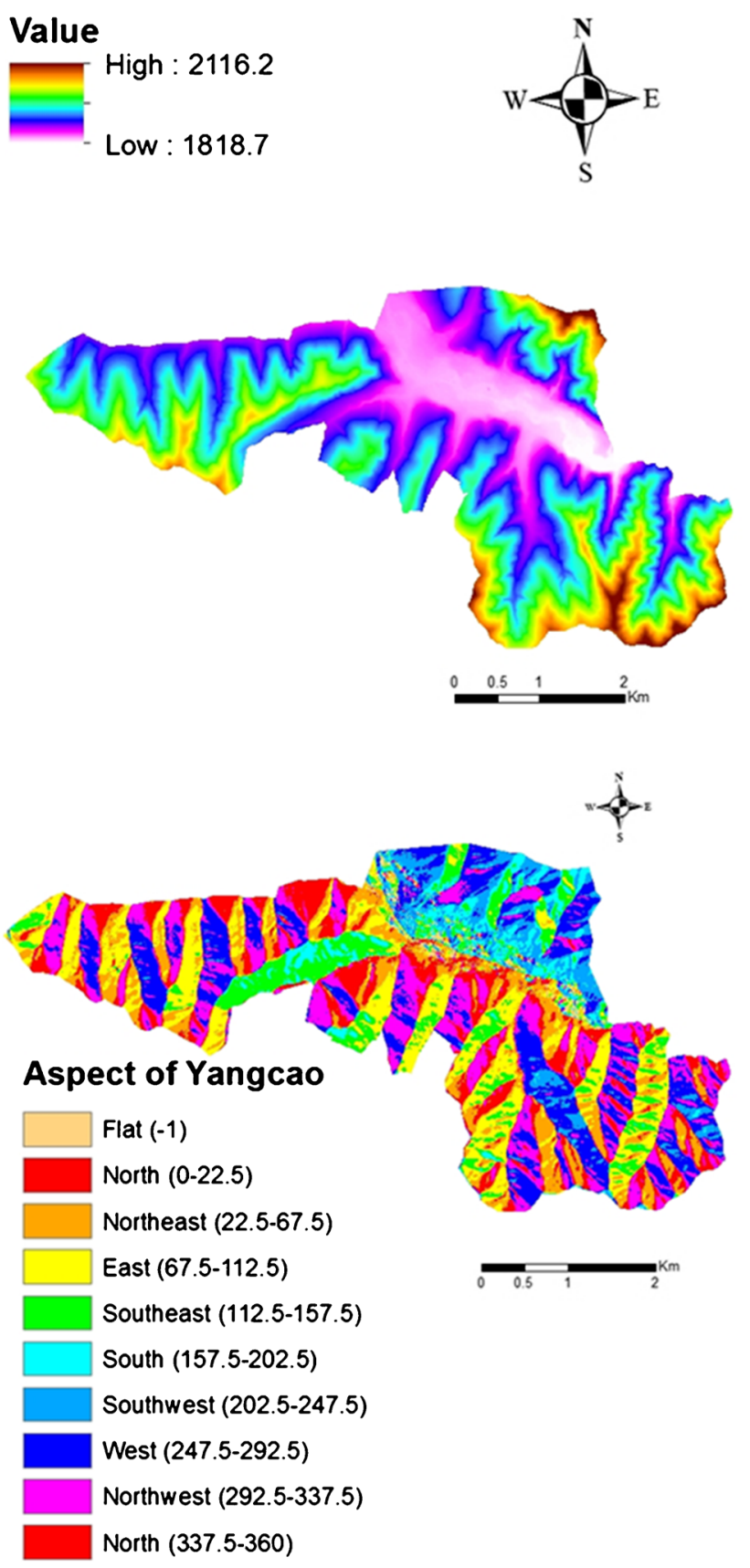

\section{Slope of Yangcao}
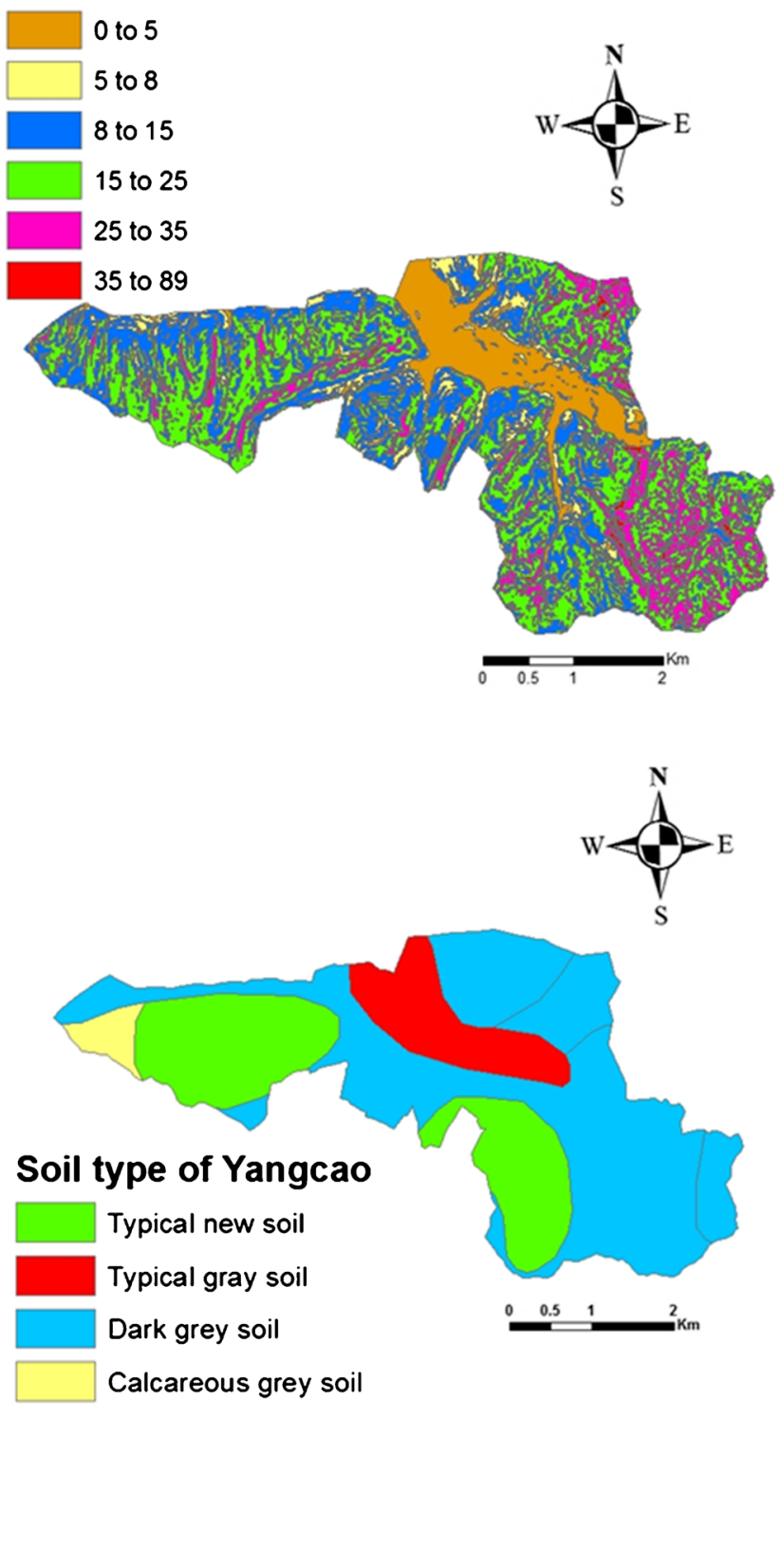

Fig. 9 Spatial distribution of DEM, slope, aspect, and soil in Yangcao city

the construction of anthropogenic activity; hence, most of these areas are characterized by the decreased vegetation cover (Koppad and Janagoudar 2017).

The increased NDVI in higher altitude areas is owing to the non-interference of human and animal activities. The aspect also is a necessary parameter to assess vegetation cover where the west and northwest direction affect vegetation cover showing high NDVI values followed by east direction which determines the vegetation cover (Solon et al. 2007). The aspect mainly influences abundance and decoration of plants community (Jafari et al. 2004). Moreover, the aspect strappingly affected the distribution patterns of incoming radiation causing alteration in vegetation pattern in the northwest direction. 


\section{Conclusion}

Guyuan district is of great economic and ecological importance for food production to China and the surrounding region. Guyuan faces numerous pressures from different natural and anthropogenic activities due to its climatic and topographic conditions. Two watershed areas were selected as a case study: Shilitan and Yangcao. This study reveals that LULC practices in Guyuan watershed area changed meaningfully from 2005 to 2019. At present, major land use in the watershed area is agricultural activities. In Shilitan and Yangcao, open woodland occupied the majority of the watershed area. Artificial grass can increase the protection of the watershed from climatic changes. The decline of open woodland in Yangcao reflects the negative impact of heavy rainfall in the study area. The increase of sloping areas reflects the hazard of any flood in the region. Woodland plays a vital role in the sustainable development of vegetation and also in the hydrology system of the city. Large areas of woodland can prevent infiltration of more rainfall and thus decrease the hazard of soil erosion. The low percentage of the sloping area can serve the environment of the watershed. It was found that the prediction of population and development requirements within this watershed boundary confirms the wise use and distribution of the limited land resources within the competing land uses. It is worth mentioning that integrating more environmental variables helps to get a more precise assessment of watershed areas. A further study is recommended to improve the woodland features for achieving sustainable development.

Funding Open access funding provided by The Science, Technology \& Innovation Funding Authority (STDF) in cooperation with The Egyptian Knowledge Bank (EKB).

\section{Declarations}

Conflict of interest The authors declare no competing interests.

Open Access This article is licensed under a Creative Commons Attribution 4.0 International License, which permits use, sharing, adaptation, distribution and reproduction in any medium or format, as long as you give appropriate credit to the original author(s) and the source, provide a link to the Creative Commons licence, and indicate if changes were made. The images or other third party material in this article are included in the article's Creative Commons licence, unless indicated otherwise in a credit line to the material. If material is not included in the article's Creative Commons licence and your intended use is not permitted by statutory regulation or exceeds the permitted use, you will need to obtain permission directly from the copyright holder. To view a copy of this licence, visit http://creativecommons. org/licenses/by/4.0/.

\section{References}

Abd El-Hamid HT (2020) Geospatial analyses for assessing the driving forces of land use/land cover dynamics around the Nile Delta Branches, Egypt. J Indian Soc Remote Sens 48:1661-1674. https://doi.org/10.1007/s12524-020-01189-2

Abd El-Hamid HT, El-Alfy MA, Elnaggar A (2020) Prediction of future situation of land use/cover change and modeling sensitivity to pollution in Edku Lake, Egypt based on geospatial analyses. GeoJournal. https://doi.org/10.1007/s10708-020-10167-7

Abdel Hamid HT, Wenlong W, Qiaomin L (2020) Environmental sensitivity of flash flood hazard using geospatial techniques Global. J. Environ. Sci. Manage. 6(1):31-46 (Homepage: https://www.gjesm. net)

Amede T, Takele B, Geta E (2001) Reversing the degradation of arable land in Ethiopian Highlands. Managing african soils 23

Basommi LP, Guan Qf, Cheng Dd (2016) Dynamics of land use change in a mining area: a case study of Nadowli District, Ghana. J Mt Sci 13:633-642. https://doi.org/10.1007/s11629-015-3706-4

Braud JA (2009) Impact of watershed delineation detail on hydrologic process modeling in low slope areas. LSU Master's Theses. 3294. https://digitalcommons.lsu.edu/gradschool_theses/3294.

CGIA (1994) A standard classification system for the mapping of land use and land cover

Chowdhury M, Hasan ME, Al-Mamun MMA (2020) Land use/land cover change assessment of Halda watershed using remote sensing and GIS. Egypt J Remote Sens Space Sci 23(2020):63-75. https://doi.org/10.1016/j.ejrs.2018.11.003

Dezso Z, Bartholy J, Pongracz R, Barcza Z (2005) Analysis of land use/land-cover change in the Carpathian region based on remote sensing techniques. Phys Chem Earth, Parts A/B/C 30(1):109_ 115. https://doi.org/10.1016/j.pce.2004.08.017

El-Hamid HTA, Caiyong W, Yongting Z (2019) Geospatial analysis of land use driving force in coal mining area: case study in Ningdong, China. GeoJournal. https://doi.org/10.1007/ s10708-019-10078-2

El-Zeiny AM, Effat HA (2017) Environmental monitoring of spatiotemporal change in land use/land cover and its impact on land surface temperature in El-Fayoum governorate, Egypt. Remote Sens Appl Soc Environ 8:266-277. https://doi.org/10.1016/j.rsase.2017.10. 003

El-Zeiny A, El-Kafrawy S (2017) Assessment of water pollution induced by human activities in Burullus Lake using Landsat 8 operational land imager and GIS. Egypt J Remote Sens Space Sci 20:S49-S56. https://doi.org/10.1016/j.ejrs.2016.10.002

El-Zeiny A, Elagami SA, Nour-Eldin H, El-Halawany ESF, Bonanomi G, Abd-ElGawad AM, Soufan W, El-Amier YA (2022) Wild plant habitat characterization in the last two decades in the Nile Delta coastal region of Egypt. Agriculture 12:108. https://doi.org/10. 3390/agriculture12010108

Haque SMS (2013) Watershed management in Bangladesh. Degradation of upland watershed in Bangladesh Project-a USDA funded Project, Grant No. BG-ARS-123, Institute of Forestry and Environmental Sciences, University of Chittagong (IFESCU), Chittagong 4331, Bangladesh.

Hong G, Abd El-Hamid HT (2020) Hyperspectral imaging using multivariate analysis for simulation and prediction of agricultural crops in Ningxia, China. Comput Electr Agricult J 172:105355. https:// doi.org/10.1016/j.compag.2020.105355

Jafari M, Zare Chahouki MA, Tavili A, Azarnivand H, Amiri GZ (2004) Effective environmental factors in the distribution of vegetation types in Poshtkouh rangelands of Yazd Province (Iran). J Arid Environ 56:627-641. https://doi.org/10.1016/S01401963(03)00077-6 
Koppad AG, Janagoudar BS (2017) Vegetation analysis and land use land cover classification of forest in uttara kannada district india using remote sensign and gis techniques. Int Arch Photogramm Remote Sens Spatial Inf Sci XLII-4/W5:121-125. https://doi.org/ 10.5194/isprs-archives-XLII-4-W5-121

Lilles T, Kiefer M (1994) Remote sensing and image interpretation. John Wiley, New York

Meshesha TW, Tripathi SK, Khare D (2016) Analyses of land use and land cover change dynamics using GIS and remote sensing during 1984 and 2015 in the Beressa Watershed Northern Central Highland of Ethiopia Model. Earth Syst Environ 2:168. https://doi.org/10.1007/s40808-016-0233-4

Meyer WB, Turner BL (1992) Human population growth and global land-use/cover change. Ann Rev Ecol Syst 23:39-61

Mustafa EK, Liu G, El-Hamid HTA, Kaloop MR (2019) Simulation of land use dynamics and its impact on land surface temperature in Beijing using satellite data. GeoJournal 86:1089-1107. https:// doi.org/10.1007/s10708-019-10115-0

OGC (2007) Guyuan yearbook 2007. Office of Guyuan Chorography, Chinese Cultural and Historical Press, Beijing, China, pp. 443. [in Chinese with English summary]

Quan B, Liu X, Lei S, Guo T, Song H, Xie J (2014) Comparison on urban land use change in China's three terrain ladders. 2014 Third International Workshop on Earth Observation and Remote Sensing Applications.
Rouse JW (2020) Monitoring the vernal advancement and retrogradation (greenwave effect) of natural vegetation. Nasa/gsfct Type Final Rep; 1974; p. E74-10113. Available online: https://ntrs. nasa.gov/citations/19740004927.

Shiferaw A (2011) Evaluating the land use and land cover dynamics in Borena Woreda of South Wollo highlands. Ethiopia J Sustain Dev Afr 13(1):87-107

Solon J, Degórski M, Roo-Zielinska E (2007) Vegetation response to a topographical-soil gradient. Catena 71:309-320. https://doi.org/ 10.1016/j.catena.2007.01.006

Tegene B (2002) Land-cover/land-use changes in the derekolli catchment of the South Welo Zone Of Amhara Region, Ethiopia. East Afr Soc Sci Res Rev 18(1):1-20

Xu JT, Cao YY (2001) Converting steep cropland to forest and grassland: efficiency and prospects of sustainability. Int Econ Rev 2:56-60

Zhen L, Deng X, Wei Y, Jiang Q, Lin Y, Helming K, Wang C, Konig JH, Hu J (2014) Future land use and food security scenarios for the Guyuan district of remote western China. J Forest 7:372-384. https://doi.org/10.3832/ifor1170-007

Zhuang L, Tian ZP, Chen YN (2012) Community characteristics of wild fruit forests along elevation gradients and the relationships between the wild fruit forests and environments in the Keguqin Mountain region of Iii. J Mt Sci 9(1):115-126. https://doi.org/10. 1007/s11629-012-2009-2 